\title{
Micrographic evaluation of different widia compositions of orthodontic pliers submitted to peracetic acid and intensive use
}

\author{
Avaliação micrográfica de diferentes composições de widia de alicates \\ ortodônticos submetido ao ácido peracético e uso intensivo
}

\section{Érika Zoli MARCIAL ${ }^{a}$ (1) , José Guilherme NEVES ${ }^{b}$ (D), Lourenço CORRER-SOBRINHO ${ }^{b}$ (D),

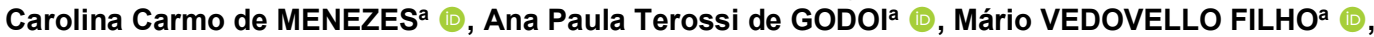 Ana Rosa COSTA ${ }^{\mathrm{a}, \mathrm{b} *}$ (1)}

aFHO - Uniararas, Programa de Pós-graduação em Odontologia, Área de Concentração Ortodontia, Araras, SP, Brasil bUNICAMP - Universidade Estadual de Campinas, Faculdade de Odontologia de Piracicaba, Departamento de Odontologia Restauradora, Divisão de Materiais Dentários, Piracicaba, SP, Brasil

How to cite: Marcial EZ, Neves JG, Correr-Sobrinho L, Menezes CC, Godoi APT, Vedovello Filho M, et al. Micrographic evaluation of different widia compositions of orthodontic pliers submitted to peracetic acid and intensive use. Rev Odontol UNESP. 2020;49:e20200021. https://doi.org/10.1590/1807-2577.02120

\begin{abstract}
Resumo
Introdução: Os procedimentos de esterilização e desinfecção devem ser adaptados ao perfil químico das ligas metálicas presentes nos instrumentos. Objetivo: 0 objetivo do estudo foi realizar uma avaliação micrográfica das características da superfície da widia de alicates ortodônticos com duas composições de ligas submetidas à ação de ácido peracético a 0,2\% e uso intensivo. Material e método: Vinte alicates de corte distal foram divididos em dois grupos ( $\mathrm{n}=10$ ), de acordo com a composição widia (\% em peso): W1- $85 \%$ a $87 \%$ de carboneto de tungstênio e outros componentes na proporção de 13\% a 15\% e W2 - 87,5\% a 88,5\% de carboneto de tungstênio e 11,5\% a $12,5 \%$ para outros componentes. Os alicates foram avaliados em uma lupa estereoscópica (32x) após três tratamentos: antes do uso (T0); após corte de 100 segmentos de fios retangulares de aço inoxidável- uso intensivo (T1); após 100 ciclos de esterilização em ácido peracético a 0,2\% e uso intensivo (T2). Os locais de corte dos alicates foram definidos pela linha "A" representando T1 e pela linha "B" representando T2. Foi realizada uma tabela de distribuição de frequências e o teste exato de Fisher $(\alpha=0,05)$. As widias foram avaliadas em MEV e Espectroscopia de Energia Dispersiva. Resultado: Os alicates W1 apresentaram defeitos significativamente menores após os ciclos de esterilização com ácido peracético e uso intensivo do que os alicates W2 ( $p=0,0198)$. Não houve diferenças entre os dois alicates após uso intensivo ( $\mathrm{p}=1.000)$. Conclusão: As imagens de MEV/EDS mostraram alterações nas superfícies widia após os diferentes tratamentos. A composição widia afetou a resistência do alicate ortodôntico após ciclos de esterilização com ácido peracético a 0,2\% e uso intensivo.
\end{abstract}

Descritores: Esterilização; ortodontia; ácido peracético.

\begin{abstract}
Introduction: The sterilization and disinfection procedures should be adapted to the chemical profile of the metal alloys present in the instruments. Objective: This study aimed to perform a micrographic assessment on the surface characteristics of the widia of orthodontic pliers with two alloy compositions subjected to the action of $0.2 \%$ peracetic acid and intensive use. Material and method: Twenty distal cutting pliers were divided into two groups ( $\mathrm{n}=10$ ) according to widia composition (\%wt): W1- $85 \%$ to $87 \%$ of tungsten carbide (TC) and other components in the proportion of $13 \%$ to $15 \%$ and W2 $-87.5 \%$ to $88.5 \%$ of tungsten carbide and $11.5 \%$ to $12.5 \%$ for other components. All the pliers were assessed in a stereoscopic magnifying glass (32x) after three treatments: before use (T0); after cutting 100 segments of rectangular stainless-steel wires - intensive use (T1); and after 100 sterilization cycles in $0.2 \%$ peracetic acid and intensive use (T2). The cutting sites of all pliers were standardized. Widia regions were defined by line "A" representing T1 and line "B" representing T2. A frequency distribution table and Fisher's exact test $(\alpha=0.05)$ was performed. We assessed two widia from each composition and treatment in SEM and energy-dispersive X-ray spectroscopy (EDS/SEM). Result: The results showed that W1 pliers presented
\end{abstract}


significantly fewer defects after the sterilization cycles with peracetic acid and intensive use than W2 pliers $(p=0.0198)$. There were no differences between both pliers after intensive use $(p=1.000)$. Conclusion: The SEM images and EDS analyses showed changes in widia surfaces after the different treatments. Widia composition affected the resistance of the orthodontic pliers after sterilization cycles with $0.2 \%$ peracetic acid and intensive use.

Descriptors: Sterilization; orthodontics; peracetic acid.

\section{INTRODUCTION}

The orthodontic community, in recent years, has been concerned with the disinfection and sterilization of orthodontic instruments, being that the dental work environment represents a high risk of contamination ${ }^{1,2}$. The concept of biosafety in dentistry is nothing more than a set of measures that should be employed in order to protect all dental staff and their patients within a clinical environment ${ }^{3}$.

Several microorganisms present in the oral cavity can survive for long periods of time outside of this environment. Exposure to the blood and saliva of patients during dental procedures leads to the possibility of acquiring diseases such as Hepatitis B and C, AIDS, among others, and being that the Hepatitis virus can survive for a week and that of AIDS for 72 hours in the environment in this context ${ }^{4,5}$, appropriate infection control procedures and sterilization of dental instruments prevent cross-contamination between patients and prevent health problems between dental office staff and the dental surgeon ${ }^{1,2,6}$.

The disinfection procedure is carried out with the aid of disinfectants and characterized by a short duration process, which can vary from a few seconds to 30 minutes. A number of factors can affect its effectiveness, such as pre-cleaning of the object, presence of organic matter, type and level of microbial contamination ${ }^{3,7}$. The disinfection can be classified into 3 types, according to their capacity: low, medium and high level. In the case of high-level disinfection, the destruction of all microorganisms (bacterial, fungal and viral), including the inactivation of resistant bacterial spores, occurs 3,7 .

Sterilization is a process in which the complete elimination of all microbial life forms, including spores, through the physical or chemical process is achieved. The most common systems of physical sterilization are steam autoclave and dry heat ${ }^{8}$. However, certain instruments cannot be sterilized with heat due to oxidation and corrosion, and the rapid deterioration of the instruments ${ }^{9}$. On the other hand, Vendrell et al. ${ }^{10}$ noted that autoclave sterilization can be used to sterilize ligature cutting pliers without causing significant deleterious effects. Although few studies have evaluated the response of the instruments to different sterilization methods ${ }^{11-13}$, it is worth noting that the equipment has undergone changes in manufacturing and that, currently, the autoclaves have a drying cycle that removes the humidity of the instruments, reducing the corrosion potential.

Chemical sterilization, however, involves the use of liquid sterilizing agents, which are the same ones used in the disinfection process, but with a longer exposure time ${ }^{14}$. Peracetic acid is a chemical agent, which has shown some advantages over glutaraldehyde in the sterilization/disinfection processes. This acid is a viable alternative since it is composed of acetic acid and hydrogen peroxide, its by-products being biocompatible substances ${ }^{15}$.

Peracetic acid is a peroxide characterized by rapid action against all microorganisms. It is a bactericidal, virucidal and sporicidal agent, whose advantage is its decomposition in non-toxic products, namely, water, oxygen and hydrogen peroxide. It is effective in the presence of organic and sporicidal matter, even in low concentrations ${ }^{2,3}$. The mechanism of action occurs by protein denaturation, increased permeability of the cell wall interrupting sulfhydryl and sulfur, and oxidation of cytoplasmic content, cell membrane, genetic material and enzymes, preventing the survival and reproduction of microorganisms ${ }^{16}$. 
Previous studies have shown that for high-level disinfection, the immersion time varies from 5 to 10 minutes and as a sterilant, they should remain between 15 to 30 minutes, varying according to the concentration and/or type of microorganisms and the presence or not of organic matter6,17. Therefore, its immersion time is considerably lower when compared to glutaraldehyde. It should be noted that peracetic acid is considered a viable alternative because it is composed of acetic acid and hydrogen peroxide and its by-products are biocompatible substances and decomposes into non-toxic products such as water, oxygen and acetic acid.

In some materials, other elements or small amounts of carbide refractories may be added to improve hardness when exposed to heat and wear resistance ${ }^{18}$. Hard metal was developed in Germany by Karl Schroter in 1923 and was composed mainly of a hard phase characterized by tungsten carbide grains (main element), which gives the material high hardness and mechanical strength; and by a binder phase (other elements), which gives tenacity and plasticity to the material. The cutting pliers with widia in their active part are indispensable for an orthodontist, expensive and the methods of sterilization or disinfection should be safe considering the health of the patients as well as the useful life of the same ${ }^{2,14}$. Although very resistant, the active tips of these pliers act by cutting steel wires of various dimensions and hardness, and with the passage of time, they suffer wear, damage and eventual loss of their efficiency ${ }^{8}$. In addition, chromed pliers may initially be more resistant to corrosion, but if surface integrity is damaged, the corrosion process is accelerated ${ }^{13}$.

On the other hand, few studies have evaluated the action of peracetic acid. Previous study observed that the disinfection with $0.2 \%$ and $2 \%$ peracetic acid did not promote corrosion in commercially pure grade 4 titanium samples ${ }^{15}$. Another study compared two stainless steel alloys and concluded that one of the alloys (type 430) should be avoided compared to disinfection with peracetic acid ${ }^{19}$. Therefore, the sterilization/disinfection procedures should be adapted to the chemical profile of the metal alloys present in the instruments and recommendations should be followed according to the manufacturers ${ }^{20}$.

Thus, until the present moment, no studies were found in literature that evaluated the action of peracetic acid $0.2 \%$ as a method of chemical sterilization in distal cutting pliers, as to the possible damages caused by this process on the active part of the pliers. Thus, the objective of this study was to evaluate the surface characteristics of two different widia compositions in the active part of distal cutting orthodontic pliers subjected to intense use, and to the action of peracetic acid and heavy use. The hypothesis of this study is that both W1 and W2 exhibit the same behavior (1) against intense use (after 100 cuts of 0.019 "x 0.025" steel rectangular wires) and (2) after 100 cycles of sterilization with peracetic acid $0.2 \%$ followed by heavy use.

\section{MATERIAL AND METHOD}

This study was approved by the ethics committee under the number: 814/2015. In this study, 20 Quinelato distal cutting pliers (Rio Claro, São Paulo, Brazil) were used and randomly divided into 2 groups $(\mathrm{n}=10)$ according to the widia composition in the active part: widia $1(\mathrm{~W} 1)$ and widia 2 (W2). The W1 pliers are composed of $85 \%$ to $87 \%$ by weight of tungsten carbide, other components in the proportion of $13 \%$ to $15 \%$ and hardness equal to 89.8 HRA. The W2 pliers are composed of $87.5 \%$ to $88.5 \%$ by weight of tungsten carbide, other components in the ratio of $11.5 \%$ to $12.5 \%$ and hardness of 90 HRA (data supplied by the manufacturer).

The pliers were randomly numbered and evaluated after three treatments in a stereoscopic magnifying glass (Olympus Corp, Lake Success, NY) with 32x magnification, as described below: T0 - without sterilization and any use to verify the integrity of the widia of the pliers; T1 - after heavy use (100 cut segments of 0.019 " x 0.025 " rectangular wires of stainless steel); and, T2 - after 100 cycles of sterilization with $0.2 \%$ paracetic acid and intense use. 
Two lines were demarcated on all pliers and designated as letters A and B (ref. Mark) for analyzes of their active part, having as reference $2 \mathrm{~mm}$ (referring to line " $\mathrm{A}$ ") and $4 \mathrm{~mm}$ (referring to line " $\mathrm{B}$ ") from the tip of the pliers (Figure 1). The demarcated region with the " $\mathrm{A}$ " line refers to the location where the 100 cut segments of the rectangular steel wire 0.019 " x 0.025 " (Morelli, Sorocaba, SP) were made and the "B" line refers to where the 100 sterilization cycles were performed in $0.2 \%$ peracetic acid followed by intense use.

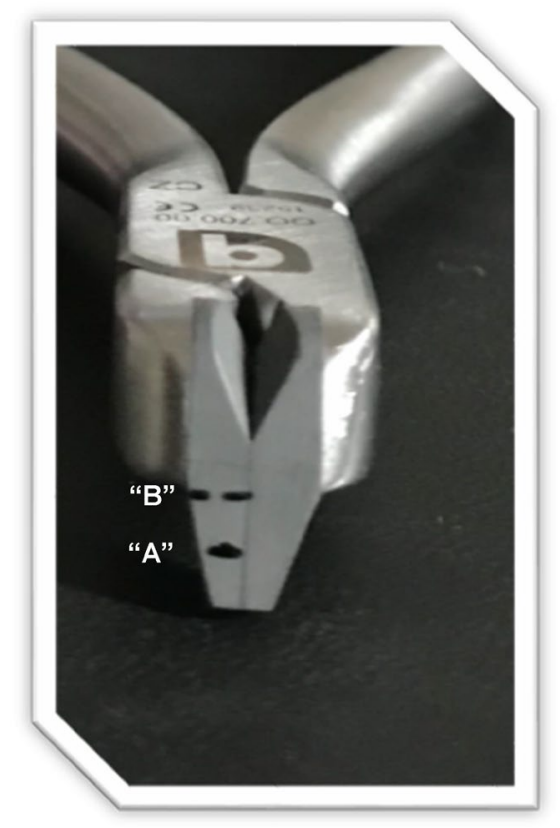

Figure 1. Distal cutting pliers. Demarcation of lines " $A$ " and "B", referring to T1 (intense use) and T2 (sterilization + intensive use).

The pliers that were submitted to 100 cycles of sterilization were immersed for 30 minutes in peracetic acid (Perax Rio 0.2\%; Rioquímica Indústria Farmacêutica Ltda, São José do Rio Preto, SP) in each cycle, followed by washing in running water and drying with sheets of paper towel, between cycles. The Perax Rio $0.2 \%$ was prepared in the powder/liquid ratio of $1 / 1$, according to the manufacturer's recommendations, where first the corrosion inhibitor of the sachet was added to the liquid contained in the flask, shaken and held for 15 minutes until the powder was completely dissolved in the liquid.

The surface topography of the widia (W1 and W2) and treatment (T0, T1 and T2) were analyzed qualitatively by Scanning Electron Microscopy (SEM) and by the quantitative analysis of X-ray Dispersive Energy (ESD). The images were performed in the Scanning Electron Microscope (MEV; LEO 435 VP, Cambridge, England) operating at 20KV, and working distance ranging from 45.2 to $49.2 \mathrm{~mm}$. Analyzes were performed to verify the presence or not of superficial changes (damages) in the structure of the widia in the active area of the orthodontic pliers. Representative images were selected (Figures 2 and 3).

\section{Statistical Analysis of Data}

Frequency distribution table and the Fisher Exact test, considering the level of significance of $5 \%$, analyzed the data. All analyzes were performed in the R Core Team program (2017). The images obtained by MEV and the data obtained by EDS were analyzed in a descriptive way. 


\section{RESULT}

No significant difference between the two types of pliers was observed regarding the percentage of damaged widia $(p>0.05)$ (Table 1$)$. In both types of pliers, only 1 in 10 pliers $(10.0 \%)$ presented superficial damage or alterations $(p=1,000)$. After the sterilization process and 100 cuts, the results showed that the widia pliers (W1) presented significantly less damage $(10 \%)$ when compared to W2 $(70 \%)(p=0.0198)$.

Table 1. Frequency (\%) of pliers with damaged widia depending on the type of pliers and the use

\begin{tabular}{ccccccc}
\hline \multirow{2}{*}{ Treatment } & \multicolumn{4}{c}{ Composition of widia } & \multirow{2}{*}{ p-value } \\
\cline { 2 - 3 } & With damage & Without damage & & With damage & without damage & \\
\cline { 2 - 3 } & $1(10.0 \%)$ & $9(90.0 \%)$ & & $1(10.0 \%)$ & $9(90.0 \%)$ & 1,000 \\
Sterilization +100 cuts & $1(10.0 \%)$ & $9(90.0 \%)$ & & $7(70.0 \%)$ & $3(30.0 \%)$ & $0.0198^{*}$ \\
\hline
\end{tabular}

*Differ statistically from each other $(\mathrm{p}<0.05)$.

The representative images obtained of the surface topography of the widia (W1 and W2) and treatments (T0, T1 and T2) with and without damages in the pliers' widia are shown in Figure 2. The chemical composition of each widia was analyzed qualitatively by the quantitative analysis of X-ray Dispersive Energy (ESD). For W1, as can be seen in Figure 3A, EDS shows the highest peak corresponding to the $\mathrm{W}$ element (Tungsten, $57.49 \%$ by weight), followed by $\mathrm{C}$ (Carbon, $25.09 \%$ by weight), 0 Oxygen, $8.40 \%$ by weight), $\mathrm{Ni}$ (Nickel, $8.17 \%$ by weight) and Co (Cobalt, $0.85 \%$ by weight). For widia W2, EDS detected a higher presence of Tungsten (W, $69.49 \%$ by weight), followed by C ( $20.35 \%$ by weight), $\mathrm{O}$ ( $5.49 \%$ by weight) and $\mathrm{Ni}$ ( $4.67 \%$ by weight) (Figure $3 \mathrm{~B})$.
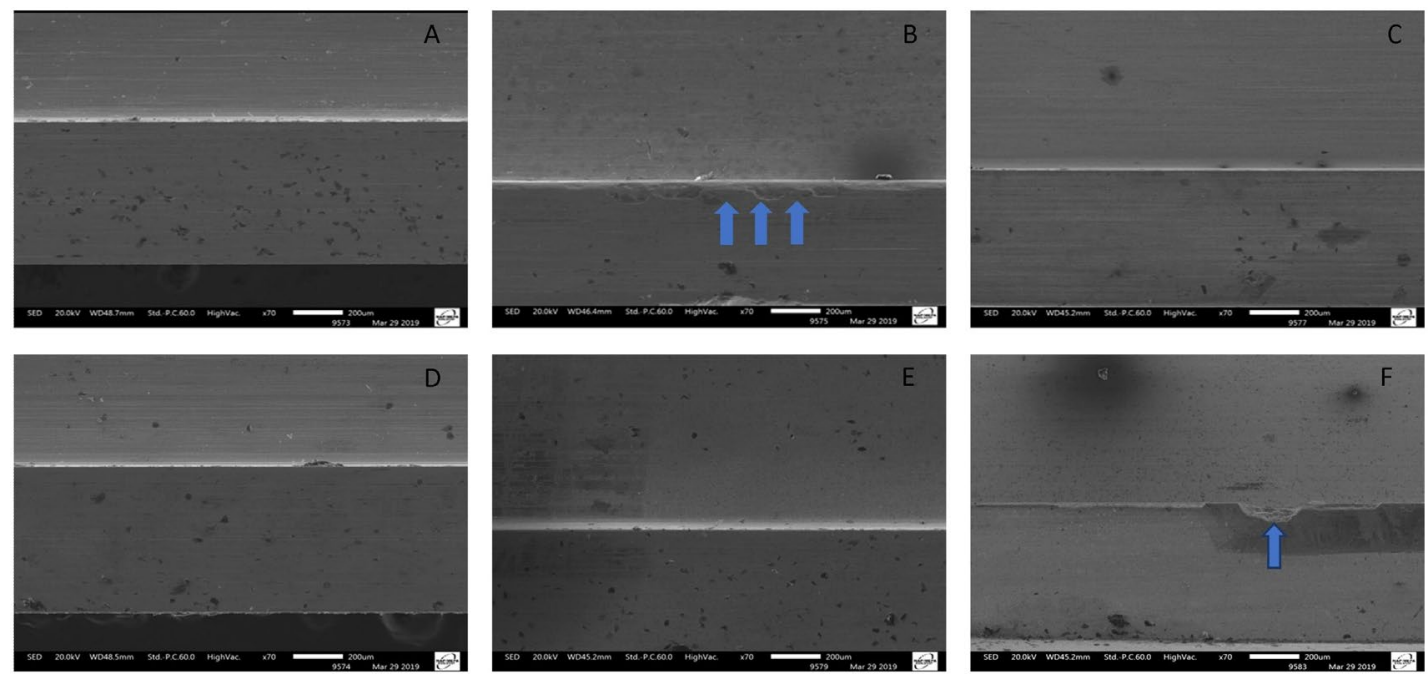

Figure 2. SEM images of the surface of W1. (A) W1 without surface treatment or use (T0), in an increase of 70x; (B) Surface with small irregularities, considered as normal or with absence of damages (blue arrows) on the W1 region after intense use (100 cuts - T1); (C) Continuous areas on the W1 region after

100 sterilization cycles with peracetic acid $0.2 \%$ followed intense use (T2). D- SEM images of the surface of W2; (D) Initial W2 (no use); Only (E) W2 after intense use (100 cuts); (F) W2 after 100 cycles of sterilization with peracetic acid $0.2 \%+$ intense use. The presence of discontinuous areas, considered as damage in 7 pliers $(70.0 \%)$ on the W2 surface of the active tip of the distal cutting pliers (blue arrow) is considered. 
A
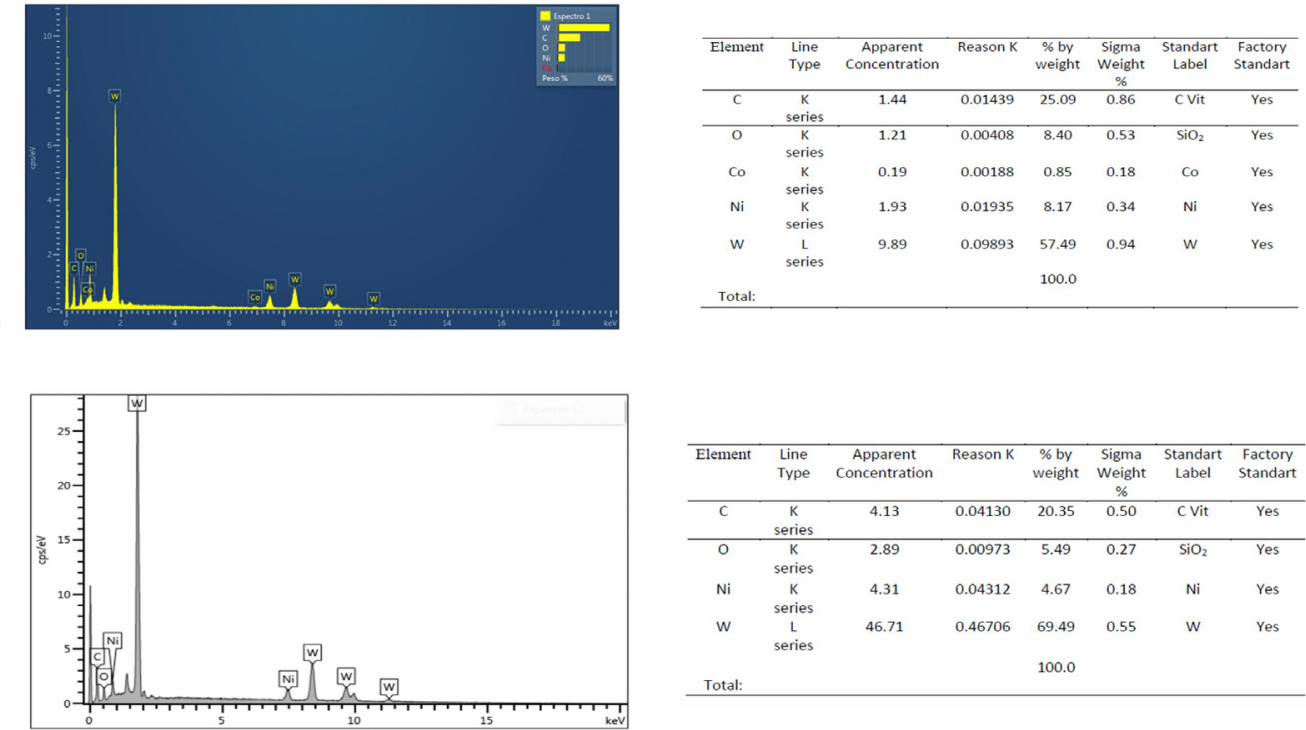

Figure 3. (A) Surface area EDS and composition of the chemical elements (\% by weight) of the W1;

(B) Surface area EDS and chemical elements (\% by weight) of.

\section{DISCUSSION}

Stainless steel pliers with widia in their active part are indispensable for the orthodontist. Although very resistant, the active tips of these pliers suffer wear, damage and eventual loss of its efficiency ${ }^{8}$ over time due to the cutting of steel wires of different dimensions and hardness. In addition, the need for sterilization of these pliers, can compromise the widia, making it less effective. Thus, the pliers selected for this study were the distal cutting pliers, because the widia of these pliers should remain intact, so that it is clinically useful, these pliers being the most used by the orthodontist and with relatively high cost. In addition, its clinical use was simulated using stainless steel wires with a larger caliper ( 0.019 "x 0.025 "), because if there was deformation on the surface of the widia, it could be more easily evaluated.

Previous study observed that the disinfection with $0.2 \%$ and $2 \%$ peracetic acid did not promote corrosion in commercially pure grade 4 titanium samples ${ }^{15}$. Another study compared two stainless steel alloys and concluded that one of the alloys (type 430) should be avoided regarding disinfection with peracetic acid ${ }^{21}$. However, until now, no studies have been found that evaluated the action of peracetic acid $0.2 \%$ as a method of chemical sterilization in the distal cutting orthodontic pliers, as to the possible damages caused by this process in the widia of the active part of these.

In this study, the influence of two widia compositions (W1 and W2) of distal cuting pliers on superficial alterations after intense use and after sterilization by peracetic acid followed by intense use was evaluated. No statistical difference was observed between the two types of pliers (W1 and W2) after heavy use ( $p>0.05)$. Therefore, the first hypothesis was accepted. After the 100 cuts of 0.019 " $x$ 0.025" stainless steel rectangular wires, in only one of the 10 pliers, for both widia, presented a surface change or damage, in relation to the images obtained initially (before any use) and after the use. According to the manufacturer's information, the W1 pliers show a hardness of 89.8 HRA and W2 90 HRA, which probably can explain the absence of statistical difference between the widia versus the intense use observed in this study.

The results obtained in this study showed that there was a statistically significant difference in relation to the surface damage in the active tip of the W2 widia ( $70 \%$ of the pliers presented defects) in relation to the widia W1 pliers (10\%) after 100 cycles of sterilization with peracetic 
acid and intense use $(p<0.05)$, rejecting the second hypothesis. On the other hand, it is worth mentioning that before the sterilization cycles, no significant change was observed in relation to the damage and/or wear on the widia of the active tip of the two types of pliers when subjected to intense use. Thus, it can be suggested that $0.2 \%$ peracetic acid has a specific action as a function of the chemical composition of the alloys of hard metal.

X-Ray Dispersive Energy Spectroscopy (Figure 3) showed that the pliers (W1) had a tungsten carbide (CW) equal to $82.58 \%$ by weight and the other components or bonding phase equal to 17 , $42 \%$ by weight. The (W2) pliers contain $89.84 \%$ by weight and other components equal to $10.16 \%$ by weight. According to the results obtained in this study, it can be suggested that W1 pliers with a lower percentage of tungsten carbide (hard phase) and higher percentage of the other elements (binder phase) suffered less damage or superficial changes, presenting higher resistance to cycles of sterilization and intense use in relation to W2 pliers, requiring a lower replacement rate of these distal cutting pliers, reducing costs.

According to the manufacturers' information, W1 pliers are composed of $85.0 \%$ to $87.0 \%$ by weight of tungsten carbide and other components in the proportion of $13.0 \%$ to $15.0 \%$. The W2 pliers are composed of $87.5 \%$ to $88.5 \%$ by weight of tungsten carbide and other components in the ratio of $11.5 \%$ to $12.5 \%$. Although the percentage by weight shown by EDS does not correspond exactly to the data provided by the manufacturer, the W2 pliers have a higher percentage of tungsten carbide (hard phase) and a lower percentage of the other elements (binder phase) in relation to W1 pliers.

The amount of binders in the metals is directly related to the properties of the hard metal (widia), ie, the greater the amount of binder, the lower the hardness of the material and the greater the resistance to fracture corroborating with the findings in this study. The W1 pliers presented higher amount of binders and consequently it was the one that presented less damage or superficial alteration $(1 / 10)$ in relation to the W2 pliers $(7 / 10)$.

According to Jones et al. ${ }^{13}$, chromed pliers may be more resistant to corrosion, but if surface integrity is damaged, the corrosion process is accelerated. In addition, the W1 alloy presents a weight percentage of Ni greater than the W2 alloy, and may suggest that the W1 alloy may be more resistant to corrosion than the W2 alloy. This may occur due to metals such as $\mathrm{Ni}, \mathrm{Ni}$-Cr and others are added to the hard metals in order to improve corrosion resistance 21.

Previous studies $1,3,15,22$ have shown that the peracetic acid sterilization and/or disinfection method can be indicated in terms of its advantages, such as: high efficiency, biocompatibility, easy handling and especially due to high level disinfection in a short time of immersion of the instruments (10 minutes) for professionals who require high rotation of the pliers. On the other hand, the sterilization/disinfection procedures should be adapted to the chemical profile of the metal alloys present in the orthodontic instruments, following the recommendations of the manufacturers ${ }^{20}$. In the present study, we observed that the variation in the chemical composition of the alloys of the orthodontic distal cutting pliers could be affected by sterilization with peracetic acid $0.2 \%$. Future studies could be performed by analyzing other types of orthodontic pliers with different types of alloys against the action of peracetic acid.

\section{CONCLUSION}

Within the limitations of this in vitro study, one can conclude that:

a) Micrographically, the W1 and W2 of the orthodontic distal cutting pliers presented the same percentage of damage or superficial alteration after intense use;

b) $0.2 \%$ peracetic acid sterilization may be indicated for $\mathrm{W} 1$ distal cutting pliers, which has lower tungsten carbide content and higher binder content in its composition, and should be avoided in W2. 


\section{REFERENCES}

1. Carrara D, Shirahige CA, Braga ACPV, Ishioka S, Sakai P, Takeiti MH, et al. A desinfecção de endoscópios com ácido peracético por dez minutos é efetiva? Rev SOBECC. 2013 Out-Dez;18(4):38-46.

2. Tengan C, Prado ID, Lima ACO, Mendes KLC, Querido SMR. Avaliação microbiológica in vitro da desinfecção de instrumentos na prática ortodôntica. Rev Cienc Salud. 2016;1(3):34-41.

3. Dourado R. Esterilização de instrumentais e desinfecção de artigos odontológicos com ácido peracético: revisão de literatura. J Biodentistry Biomater. 2011;(2):31-45.

4. Golegã AAC. Controle de infecção e a prática odontológica em tempos de AIDS: manual de condutas. Brasília: Ministério da Saúde; 2000.118 p.

5. Zenkner CL. Infecção cruzada em odontologia: riscos e diretrizes. Rev End Pes Ens Online. 2006;2(3):1-7.

6. Carvalho MRA, Silva MAS, Brito CAS, Campelo V, Kuga MC, Tonetto MT, et al. Comparison of antimicrobial activity betwen chemical disinfetants on contaminated orthodontic pliers. J Contemp Dent Pract. 2015 Aug;16(8):619-23. http://dx.doi.org/10.5005/jp-journals-10024-1731. PMid:26423496.

7. Guimarães J. Controle de infecção cruzada no consultório odontológico. Rev Assoc Paul Cir Dent. 1992;46:711-6.

8. Mizrahi E, Cleaton-Jones PE, Luyckz S, Fatti LP. The effect of íon implantation on the beaks of orthodontic pliers. Am J Orthod Dentofacial Orthop. 1991 Jun;99(6):513-9. http://dx.doi.org/10.1016/S0889-5406(05)81627-0. PMid:2038970.

9. Matlack RE. Instrument sterilization in orthodontic offices. Angle Orthod. 1979 Jul;49(3):205-11. http://dx.doi.org/10.1043/0003-3219(1979)049<0205:ISIO0>2.0.CO;2. PMid:384851.

10. Vendrell RJ, Hayden CL, Taloumis LJ. Effect of steam versus dry- heat sterilization on the wear of orthodontic ligature-cutting pliers. Am J Orthod Dentofacial Orthop. 2002 May;121(5):467-71. http://dx.doi.org/10.1067/mod.2002.122175. PMid:12045764.

11. Custer F, Andersen RA. A study of surface changes in instruments during sterilization procedures. N Y J Dent. 1968;38(1):8-17. PMid:5234955.

12. Custer F, Coyle T. Instrument changes during sterilization. J Dent Res. 1970;49(3):487-95. http://dx.doi.org/10.1177/00220345700490030401. PMid:5269100.

13. Jones M, Pizarro K, Blunden R. The effect of routine ateam autoclaving on orthodontic pliers. Eur J Orthod. 1993 Aug;15(4):281-90. http://dx.doi.org/10.1093/ejo/15.4.281. PMid:8405133.

14. Almeida CMF, Carvalho AS, Duarte DA. Avaliação dos métodos de desinfecção de alicates ortodonticos. Dental Press J Orthod. 2012;17(4):105-9. http://dx.doi.org/10.1590/S2176-94512012000400020.

15. Raimundo LB, Orsi IA, Kuri SE, Rovere CA, Busquim TP, Borie E. Effects of peracetic acid on the corrosion resistance of commercially pure titanium (grade 4). Braz Dent J. 2015 Dec;26(6):660-6. http://dx.doi.org/10.1590/0103-6440201300511. PMid:26963213.

16. McDonnell G, Russell AD. Antiseptics and disinfectants: activity, action and resisntance. Clin Microbiol Rev. 1999 Jan;12(1):147-79. http://dx.doi.org/10.1128/CMR.12.1.147. PMid:9880479.

17. Rutala WA, Weber DJ. How to assess risk of disease transmission to patientes when there is a failure to follow recommended disinfection and sterilization guidelines. Infect Control Hosp Epidemiol. 2007 Feb;28(2):146-55. http://dx.doi.org/10.1086/511700. PMid:17265395.

18. Torres CS, Schaeffer L. Sinterização do compósito metal duro WC-Co. Revista Eletrônica de Materiais e Processos. 2009;4(3):58-63.

19. Black E, Owens K, Staub R, Li J, Mills K, Valenstein J, et al. Evaluation of AISI type 304 stainless steel as a suitable surface material for evaluating the efficacy of peracetic acid-based disinfectants against 
clostridium difficile spores. PLoS One. 2017 Oct;12(10):e187074.

http://dx.doi.org/10.1371/journal.pone.0187074. PMid:29065168.

20. Benyahia H, Merzouk N, Ebn Touhami M, Zaoui F. Effects of sterilization and disinfection procedures on the corrosion of orthodontic ligature cutters. Int Orthod. 2012 Mar;10(1):1-15.

http://dx.doi.org/10.1016/j.ortho.2011.12.007. PMid:22244107.

21. Wentzel EJ, Allen C. Erosion-corrosion resistance of tungsten carbide hard metals with different blinder compositions. Wear. 1995;181-183:63-9. http://dx.doi.org/10.1016/0043-1648(94)07014-8.

22. Lemmer K, Howaldt S, Heinrich R, Roder A, Pauli G, Dorner BG, et al. Test methods for estimating the efficacy of the fast-acting disinfectant peracetic acid on surfaces of personal protective equipament. J Appl Microbiol. 2017 Nov;123(5):1168-83. http://dx.doi.org/10.1111/jam.13575. PMid:28853204.

\section{CONFLICTS OF INTERESTS}

The authors declare no conflicts of interest.

\section{*CORRESPONDING AUTHOR}

Ana Rosa Costa, FHO - Uniararas, Programa de Pós-graduação em Odontologia, Área de Concentração Ortodontia, Av. Dr. Maximiliano Baruto, 500, 13607-339 Araras - SP, Brasil, e-mail: anarosacosta@fho.edu.br; anarosacosta_1@hotmail.com

Received: March 29, 2020

Accepted: May 19, 2020 